\title{
Correction to: Case report: appendicitis induced Staphylococcus aureus and Klebsiella pneumoniae bacteremia in a young healthy male
}

Jan Arne Deodatus*, Sander Ferdinand Emiel Paas, Gerrit Hendrik Johan Wagenvoort and Marije Matilde de Kubber

\section{Correction to: Int J Emerg Med 14, 36 (2021)}

https://doi.org/10.1186/s12245-021-00358-5

Following publication of the original article [1], the corresponding author reported that their middle name, Arne, was repeated in the authorship panel.

The correct authorship list is available in this Correction article and the author apologizes for the error.

The original article [1] has been corrected.

Published online: 01 November 2021

\section{Reference}

1. Deodatus JA, Paas SFE, Wagenvoort GHJ, et al. Case report: appendicitis

induced Staphylococcus aureus and Klebsiella pneumoniae bacteremia in a young healthy male. Int J Emerg Med. 2021;14(1):36. https://doi.org/10.1186/ s12245-021-00358-5.

The original article can be found online at https://doi.org/10.1186/s12245021-00358-5.

*Correspondence: arnedeodatus@gmail.com

Isala Hospital, Dokter van Heesweg 2, 8025, AB, Zwolle, The Netherlands

(c) The Author(s). 2021 Open Access This article is licensed under a Creative Commons Attribution 4.0 International License, which permits use, sharing, adaptation, distribution and reproduction in any medium or format, as long as you give appropriate credit to the original author(s) and the source, provide a link to the Creative Commons licence, and indicate if changes were made. The images or other third party material in this article are included in the article's Creative Commons licence, unless indicated otherwise in a credit line to the material. If material is not included in the article's Creative Commons licence and your intended use is not permitted by statutory regulation or exceeds the permitted use, you will need to obtain permission directly from the copyright holder. To view a copy of this licence, visit http://creativecommons.org/licenses/by/4.0/ The Creative Commons Public Domain Dedication waiver (http://creativecommons.org/publicdomain/zero/1.0/) applies to the data made available in this article, unless otherwise stated in a credit line to the data. 